\title{
Orta Çağ'da Yaşamış iki Alman Esirin Gözünden Osmanlı- Türk Toplumunda Sosyal Değerler
}

\author{
Ali Osman Öztürk (iD, Konya \\ https://dx.doi.org/10.37583/diyalog.802161
}

\section{$\ddot{o}_{z}$}

Johannes Schiltberger, 1394-1427 yılları arasında Türkiye, Suriye, Mısır, İran, Orta Asya ve Sibirya'da esir olarak yaşayıp gördüklerini "Türkler ve Tatarlar Arasında (1394-1427)" başlıklı kitabında yazıya geçirir. Çok değişik insan coğrafyalarında bulunmuş olmasından dolayı Schiltberger'in Türkleri insani özellikleri bakımından diğer halklarla karşılaştırma yoluna gideceğini varsayıyoruz. Hans Ulrich Krafft ise 24 Ağustos 1574 yılında borç yüzünden Osmanlı-Türk makamlarınca tutuklanır. 24 Ağustos 1577 yılında tahliye edilir ve memleketine dönmek üzere yola çıkar ve ancak 9 Aralık 1578'de vatanına kavuşur. Mesleği tacirlik olan H. U. Krafft'ın Osmanlı toplumunda geçerli ticaret ve ticari ilişkiler hakkında hassasiyeti olacağından, gözlemlerinde bunlara yer vereceğini düşünüyoruz. Bu makalede her iki Almanın anılarında İstanbul'un fethi öncesi ve sonra sosyal hayatta gözlemlenen değerler ve değer yargıları ele alınacaktır. Öncelikle sosyal, ahlaki, insani değerler her bir eserde tespit edilecek, sonra bunlar 150 yıllık süre bağlamında karşılaştırılarak Osmanlı-Türk Toplumunda değerler değişimi olup olmadığı ve var ise bunların olası nedenleri üzerinde duracağız.

Anahtar Sözcükler: Ortaçağ, Osmanlı Türk Toplumu, Sosyal değerler, toplumsal değişim.

\begin{abstract}
Social Values in the Ottoman-Turkish Society through the Eyes of Two German Prisoner-Travelers in the Middle Ages

Johannes Schiltberger wrote what he lived as a prisoner in Turkey, Syria, Egypt, Iran, Central Asia, and Siberia between 1394-1427 in his book titled "Reisen des Johannes Schiltberger. Aus München in Europa, Asia und Afrika von 1394 bis 1427". We assume that Schiltberger will compare Turks with other societies in terms of their humanistic characteristics since he visited various human geographies. Moreover, Hans Ulrich Krafft was arrested by the Ottoman-Turkish authorities on August 24, 1574, because of the debt. He was released on 24 August 1577 and set out to return to his hometown, but he reached his homeland on 9 December 1578. We believe that H. U. Krafft, whose profession was a trader, had an awareness of the current trade and commercial relations in the Ottoman society, and that he will include them in his observations. In this article, the values and judgments observed in social life before and after the conquest of Istanbul in the memories of both Germans and Ottomans will be discussed. First of all, social, moral, and human values will be defined in each work, and then they will be compared in the context of 150 years. We will evaluate whether there are any changes in the Ottoman-Turkish Society and if so, we will analyse any possible causes for these changes.
\end{abstract}

Keywords: Medieval, Ottoman Turkish Society, Social values, Social change

Einsendedatum: 03.04.2020

Freigabe zur Veröffentlichung: 30.09.2020 


\section{EXTENDED ABSTRACT}

Johannes Schiltberger wrote about what he lived as a prisoner in Turkey, Syria, Egypt, Iran, Central Asia, and Siberia between 1394-1427 in his book titled "Reisen des Johannes Schiltberger. Aus München in Europa, Asia und Afrika von 1394 bis 1427". We assume that Schiltberger will compare Turks with other societies in terms of their humanistic characteristics since he visited various human geographies.

Moreover, Hans Ulrich Krafft was arrested by the Ottoman-Turkish authorities on August 24, 1574, because of the debt. He was released on 24 August 1577 and set out to return to his hometown, but he reached his homeland on 9 December 1578 . We believe that H. U. Krafft, whose profession was a trader, had an awareness of the current trade and commercial relations in the Ottoman society, and that he will include them in his observations.

When we consider the years that these people left Turkey, in the following 150 years' period, the Ottoman empire has conquered Istanbul, and the empire was living its "magnificent century" in Sultan Suleiman's reign. At the zenith of state power and wealth, the society was very self-confident. However, the observations of two Germans who dealt with people rather than the state as a prisoner/captive can provide us with interesting data.

In this article, the values and judgments observed in social life before and after the conquest of Istanbul in the memories of both Germans and Ottomans have been discussed. First of all, social, moral, and human values have been defined in each work, and then, they have been compared in the context of 150 years. We have evaluated whether there are any changes in the Ottoman-Turkish Society and analysed any possible causes for the changes.

We highlighted the following issues through the relationship between beard and arrogance, respect for beliefs, the position of women, the justice mechanism, and the problem of gratuity and/or bribery:

As J. Schiltberger explains in the example of Muslims, the principle that putting forward the similarities of religions will facilitate coexistence with people of different religions. From today's perspective, this is one of the most reasonable ways to tolerate differences in our country as well as for Muslims living in Europe.

H. U. Krafft, as a prisoner charged with crime, has experienced the phenomenon of alienation and marginalization more deeply than J. Schiltberger. Since he was mostly concerned with the legal dimension of social life, he had the opportunity to observe the behaviours that were punished or not.

While his experience with wine as a Christian allows us to explain that Muslims' tolerance and respect are not limitless as a social value, he also criticizes the flattering and hypocritical personalities through a sect leader who preaches loudly at midnight or in the morning for showing off. We also see this hypocrisy in people who do their jobs and duties by accepting bribes, tips, and gifts and present themselves as facilitators. It would be better to describe these issues not as social values but as deficiencies.

In my opinion, what H.U. Krafft says about the Ramadan Fasting, which he mentions as a religious practice, and about the rights of Muslim women in marriage is of great social significance. Fasting means solidarity and cooperation, which includes 
even foreign prisoners in the Ottoman society. According to the marriage law, a woman could file charges against her husband and put him in prison if she is neglected and abused in her marriage. At that time, this reflects a very positive social condition compared to that of Europe.

Krafft regarded male jealousy in marriage (which can be interpreted positively or negatively according to the point of view), as a factor that restricts women's freedom of movement on streets. The fact that women and men (even if married), were not welcomed to talk to each other in public places, and it may exhibit a socially interesting circumstance. Why do two people talking in front of everyone disturb the society? Why do their conversation and privacy concern other people? Why is the individual's sense of curiosity so permitted and encouraged in the Muslim community? We should question why members of a religion that orders to cover up each other's flaws tend to create potential flaws from innocent situations, and whether it is a social value or worthlessness.

The descriptive scanning method has been adopted in the article, and the results have been reached by interpreting the social values inferred from the data obtained from the works. 


\title{
0. Giriş
}

Edward Said'in literatüre kazandırdığı hayali/tasarlanmış bir öteki kurgusu (1991: 14) olan oryantalizmi besleyen kaynaklar arasında geçmişte Doğu'yu bizzat gören gezginlerin gözlemleri ve yazdıkları günceleri de önemli yer tutmaktadır. Bozkurt Güvenç, bu kapsamda İtalya, Almanya, Avusturya, İngiltere, Fransa, Amerika gibi ülkelerdeki Türk imajlarının, doğulu olarak Türk kimliğinin bir parçası olduğu tezini savunmaktadır (1994: 290-333). Çünkü batının gözünde Doğu/Şark yekparedir ve öz kendini nasıl tanımlarsa tanımlasın, ötekinin gözünde bir “öteki”dir, dolayısıyla söz konusu imge, onun (bilinçli ya da bilinçsiz) algısıyla sınırlıdır. Algının sınırları bazen ötekini, özün tersi olarak görecek denli daralabilir. Avrupa'da Türk imgesi bağlamında Pierre Béhar;

\begin{abstract}
gerçekte barbar, ex definitione Öteki'dir, yani kültürü olmayan kişi değil - buna vahşi denir -, aksine tıpkı Türk örneğindeki gibi, farklı kültürden olan kişidir. Dahası var: Onun kültürü Hıristiyan kültüründen yalnızca farklı değildir, aynı zamanda bu kültürün tersidir. Türk, herşeyin tam aksini yapan bir varlıktır: Türkün erkeği, kaftan dediği uzun [etekli] elbiseler giyerken, kadını da bir erkek gibi pantolon [şalvar] giyer. Bir Hıristiyanın aksine Türk, birçok kadına sahip olma hakkına sahiptir; zenginse aynı zamanda, fakirse ard arda; Türk yere oturur, ve yerde oturarak yemek yer; yazıyı tersden yazar: sağdan sola; çişini öbür türlü, kadın gibi eğilerek yapar; nihayet birini öldürürse, bunu ters bir şekilde, yani kafasını uçurarak değil, kazığa geçirerek yapar. Kısacası, Türk Avrupalının tam bir karşııtıdır (1994: 92)
\end{abstract}

diyerek, bununla tarihten beri süregelen Avrupa'da Türkler hakkında kalıpsal önyargılara işaret eder. Nitekim örneğin H. Ulrich Krafft, Müslümanlar için benzer tespitlerde bulunur:

Camiye girerken ayakkabılarını çıkarırlar ve başlarını [takkeyle] kapalı tutarlar. Biz de ise bunun tersi yapıllvr. ${ }^{2}$ İbadet ederken oturup yere bakarak sağa sola sallanırlar [?]. Biz Hiristiyanlar ise diz çöküp ya da ayakta sabit durup gökyüzüne bakarız. Bir cenazeyi mezara götürürken, kapıdan, önce başı dışarı çıkarırlar, halbuki, biz Hıristiyanlar kendi ölülerimizin ayaklarını önce çıkarııı. Ve onlar cenazenin arkasından kadın, çocuk ve akrabalar, bazen ağlaşarak, yürürken, bizde sessizlik esastır. Şayet ibadet için, özellikle cuma günü, ki bugün onların pazarıdır, camiye gitmek isterlerse, bunu öğleyin, yiyip içtikten sonra yaparlar. Bizde ise en büyük ibadet öğlenden önce aç karna yerine getirilir. Biz Hıristiyanların tatili pazar günüdür. Müslümanlar, Tanrı'nın daha çok hoşuna gitsin diye bizlerden önce cuma ibadetini yaparlar. Türkler yemin ederken bir, Hıristiyanlar ise iki parmaklarını kaldırırlar... İster çalışsınlar, ister yiyip-içsinler, isterse uyusunlar, herşeyi yerde yaparlar. Duruşmaları da, danışmaları da, yazı yazmak, para saymak, tek kelimeyle, ayağa kalkmadan yapılacak her şeyi yerde hallederler. Uyumak istediklerinde, ev sahipleri çoğunlukla yatağı yemek yedikleri yere sererler. Giysilerinden çok azını çıkarır, bir yorganı yere serdikten sonra başka bir yorganla örtünürler, öyle ki, yorgana geçirilen yüz yukarı gelir, biz de ise alta çevrilir. Bizde her şeyin tersi yapılır. Müslümanlarda iki, üç veya dört kadınla evlenme adeti var. Zenginler ve durumu iyi olanlar daha fazla alabilirler. Evlilikte biz Hiristiyanlarda bir kadindan fazlasına izin yoktur. (...) Sade elzenaatkârları veya köylüler, günlük kıyafet içinde pantolonsuz gezerler. Kadınlarsa, fakir olsun zengin olsun hep pantolon giyerler. Bizde bunun tersi olur. Türklerin çoğunluğu, zengin ya da fakir, demir [nalça] ve çiviyle beslenmiş ayakkabılar giyerler. Atlarının çoğunu ise kumlu zeminde nallatmadan

\footnotetext{
${ }^{2} \mathrm{Bu}$ ve aşağıdaki vurgulama tarafımızdan yapılmıştır.
} 
kullanırlar. Bizde böyle şey olmaz. Nihayet bir şey daha; sade yurttaşın karıları, kocalarını, şayet haklarını vermiyor, ondan artık hoşlanmıyor ve başka birini seviyor iseler, hakime şikayet edebilme adeti ve özgürlüğüne sahiptir. Böyle bir adam cezalandırılır (...) Biz Avrupalılar, özellikle Almanlar, böyle bir durumda kadınları bir güzel pataklarız. (1996: 52-55, passim)

Değişik sebeplerle Türk ve Müslüman ülkelere seyahat eden ya da buralarda esarete düşüp yaşamak zorunda kalan yabancilar da gözlemlerini bu perspektiften yapagelmişlerdir. Bu açıdan seyyah ve esirlerin Avrupa yaşam kültürünün tersi olarak algılanan Osmanl1-Müslüman toplumunun değer yargılarını nasıl gördükleri bize ilginç ipuçları verebilir. Bu noktadan hareketle bu makalede biri esir, biri mahpus iki Alman seyyahın anılarında, söz konusu bakış açısına rağmen Osmanlı Türk toplumunda hangi sosyal değerleri önemsediklerini ortaya koymaya çalışacağız. Ele alacağımız yazılı kaynaklar, 1394-1427 ve 1574-1577 yılları arasında yaşamlarını zaruri nedenlerle Osmanlı topraklarında geçirmek zorunda olan iki Alman'ın gözlemlerini aktarmaktadır. Daha önce aynı dönemleri yansıtan gezi notları ve günceleri (Schweigger 1964, 2004; Dernschwam 1923, 1992 ve Buspecq 1926, 2011; Tebly 1988) yayınlanmış olup, zamanın sosyal yaşamıyla ilgili değerlendirmeler yapılmıştır (örn. Önen 1977: 1-16; Buch 1982: 745-786; Çetin 2011: 39-58 ve Schlemmer 1996: 57-83). Schweigger, Dernschwam ve Busbecq üst kesimden özgür kişiler olarak Türkleri tanıma firsatı bulmuşken, Schiltberger ve Krafft Osmanlı topraklarında tutsak olarak bulunmuşlardır. $\mathrm{Bu}$ nedenle iki grubun Osmanlı/ Türk/Müslüman algısı arasından belirgin bir fark olabilir ${ }^{3}$. Ancak, bu çalışmada iki seyyahın yüz elli yıl ara ile yaptığı gözlemleri arasındaki fark ve benzerliğe odaklanarak, adı geçen diğer gezi notu ve günce yazarlarının statüsünü dikkate alarak yapılacak yeni araştırmalar için bir zemin oluşturabilmeyi amaçlıyoruz. Yazının sonunda Osmanlı Türk toplumunda yüz elli yıl sonra sosyal, ahlaki, insani değerler açısından değişim olup olmadığı ve var ise bunların olası nedenleri üzerinde duracağı. ${ }^{4}$

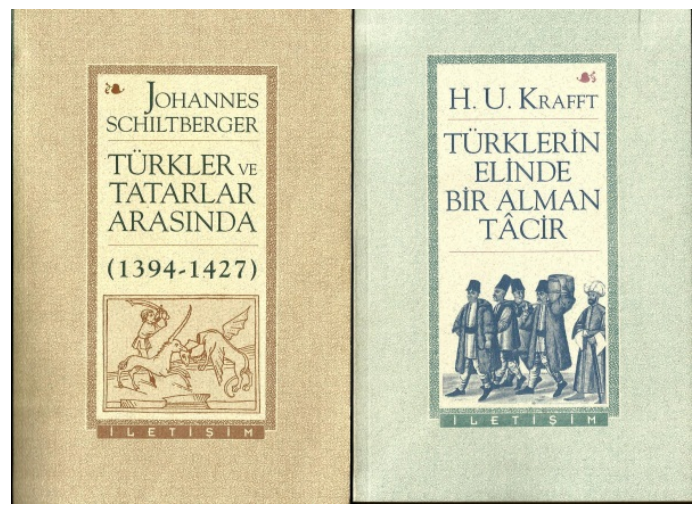

Schiltberger 1995 ve Krafft 1996

\footnotetext{
${ }^{3}$ Örn. Krafft'ın anılarının kendisi gibi eğitimsiz olan çağdaşı Samuel Kichel (gezisi 1585-1588 yılları arasını kapsamaktadır) gözlemleriyle karşılaştırılması için bkz. Buch 1982.

${ }^{4} \mathrm{Bu}$ makalede araştırma malzemesi olarak her iki kitabın Turgut Akpınar tarafından gerçekleştirilen Türkçe çevirisi kullanılacaktır (bkz. Schiltberger 1995 ve Krafft 1996).
} 


\title{
1. Johannes Schiltberger
}

Johannes Schiltberger (1381-1440), 16 yaşında 1396 tarihli Niğbolu Muharebesine katılmış ve savaş sonunda Türklere tutsak düşmüş bir Almandır. Rivayete göre bu muharebede 60.000 şehit veren Osmanlı Padişahı Yıldırım Bayezid, bunun intikamını sayısı on binlere varan esirin kafasını kestirmek yoluyla almış. Schiltberger, o sırada henüz çok genç olduğundan, şehzadenin, 20 yaşın altındakilerin affedilmesi ricası üzerine kurtulmuştur. Bursa'ya gönderilen Schiltberger 1402'ye kadar Bayezid'in emrinde bulunur ve Ankara Meydan savaşından sonra da Timur'un esirleri arasında kalır. Timur'dan sonra oğulları Şahruh ve Miranşah'ın yanında tutsaklık yaşamını sürdürür; 1408 tarihinde Karakoyunlu Kara Yusuf'a karşı verdiği savaşta ölümü üzerine onun ikinci oğlu Ebubekir'in kölesi olur. Ebubekir'in emri üzerine Çekre adındaki bir hanın maiyetine katılır; onunla birlikte Edigu (Edegu)'nun peşinden Sibirya üzerine bir sefere çıkar. Schiltberger son olarak Tataristan dediği Kırım ve ötesi ülkelerde bulunmuştur. Nihayet Çerkes ülkesindeyken beyinin yanından kaçar ve Batum, Amasra, Sinop, İstanbul, Akkirman, Limburg, Krakau, Breslau, Eger, Regensburg ve Landshut üzerinden doğduğu yer olan (Münih civarındaki) Freising'e ulaşır.

Schiltberger'in hatıratında (1995), en çok üzerinde durulan konular; dini inanış ve pratikler, tutsak olarak gezdiği geniş coğrafyada bulunan büyük şehirler, gördüğü veya duyduğu olaylar, efsaneler, mezarlar ve özel yerler, bazı tarihsel kişilikler ile ilgili inanışlar; ayrıca ölü gömme, evlenme, yeme-içme adetleri, halk tababeti vs.dir.

\subsection{Schiltberger'e Göre Osmanlı Toplumunda Sosyal Değerler ${ }^{5}$}

\subsubsection{Din}

Schiltberger'in gözlemleri arasında din önemli bir yer tutmaktadır (1995: 173-197). Bu kapsamda mescit, medrese, cami, imaret gibi dini mekânlar; Ramazan ve Kurban bayramları gibi dini törenler; sakal, başörtüsü ve evlenme adabı gibi kültürel değerler ön plandadır. Sakal bırakmayı, Hz. Muhammed'in kanun olarak koyduğu bir emir sayar.

\begin{abstract}
Evvela o, Müslümanlara sakallarını kesmeyi yasakladı, çünkü bu, ilk insan olarak Adem'i kendi ilahi şekline göre yaratmış olan Tanrının iradesine aykırı olurdu. Bu sebeple, Müslümanlar, Tanrının kendisini yarattı̆̆ından başka türlü görünenler, genç olsun yaşlı olsun Tanrının iradesini değiştirmiş ve ona aykırı davranmış olmaktadır, derler. Ayrıca sakalını kesen bir kimsenin kibirli ve mağrur olduğu ve dünyada hoşa gitmek için süslendiği kanaatindedirler. Böylelikle o, ilahi yaratımı hor görmüş olur. Bunu özellikle Hıristiyanlar, karılarının hoşuna gitsin diye yaparlar. (1995: 160)
\end{abstract}

Buna benzer bir açıklamayı Rumlardan söz ederken de yapar Schiltberger: "[Rumların] iddiasına göre, rahipler sakallarını tıraş ederlerse büyük bir günaha girmiş olurlar, zira bu dindarca bir davranış olmayıp, züppece bir şeydir ve kadınların hoşuna gitmek için yapilmaktadır.", (1995: 183)

\footnotetext{
${ }^{5}$ Aşağıdaki bazı notlar için bkz. Öztürk 1997a: 54-58 ve 1997b: 55-60. Akbulut'un G. Simes'e dayanarak belirttiği gibi (bkz. 2019: 137), Schiltberger'in anılarının gerçekliği ne ölçüde yansıttığı konusu tartışmalıdır. Ancak Almanya'da yayınlanan anıların “ötekinin” bakış açısını yansıttığı düşüncesiyle, anlatılanların gerçekliği hususu dikkate alınmaksızın değerlendirme yapılacaktır.

${ }^{6}$ Ama sonraki yüzyıllarda Hıristiyan din adamları da sakallarını kesmişlerdir.
} 
Schiltberger'in hatıratı çokça efsanevi hikâyelerle süslenmiştir. Bunların gerçekliği tartışmalıdır. Ancak, anlatılan (efsanevi) bir hikâyenin ahlaki mesajını önemli saymamız gerekiyor. Kibirin (büyüklenmenin) toplumca hoş karşılanmadığını göstermesi bakımından "Atmaca Kalesi” hikâyesi özellikle dikkate alınmalıdır, çünkü yukarıdaki davranış ilkesini destekler niteliktedir:

\begin{abstract}
Bir dağda 'Atmaca Kalesi' denilen bir kale vardır. İçinde güzel bir bakire, tünek'e tünemiş bir atmaca ile birlikte yaşar. Oraya herhangi bir kimse gelip de üç gün, üç gece hiç uyumadan nöbetçi kalırsa o zaman bu kızdan bir dilek dileyebilir. Bu dilek şerefli bir istek ise arzusu yerine getirilir. (...) Fakat bir kimse, kibirlice, iffetsizce ve kabaca dileklerde bulunursa, bakire onu ve ailesini, soyunu öyle lanetler ki o bir daha iflah olmaz. (1995: 103)
\end{abstract}

Kibrin kötülüğü yanında Müslümanların, özellikle zenginlerin fakirlere karşı alçak gönüllü olmaları gerektiğine (1995: 166), böylece Tanrı'nın kendilerine güç kuvvet bağışlayacağına inandıklarını belirten Schiltberger, ticarette de güzel bir gelenekten bahseder:

Bir kimse kimden olursa olsun bir şey satın almaya kalkışınca, satıcıya şunu söyler: 'Sen, geçinebilmen için, (ancak) Tanrının öngördüğ̈̈ kadar kazanmalısın. (Fazlasını değil).’ Bunun üzerine tacir, kırk parada bir para veya kırk altında bir altından fazlasını alamaz. Buna onlar, 'Allah'ın hoşuna giden satın alma ve kazanç' derler. Bunu onlara Muhammed emretmiştir, şu anlamda ki herkes biri birinden geçinir, fakir zenginden. Her vaazdan önce, hocaları onlara, birbirlerine karşı yardım etmelerini ve hükümdara karşı itaatkar olmalarını, söyler. (...) Müslümanlar, hocalarının ilahi işler hususunda söylediklerine inanırlar ve bu sözlere riayet ederler. (1995: 166 vd.)

\title{
1.1.2. Dinde Hoşgörü ve Saygı
}

Schiltberger (1995), Müslümanların Hıristiyanlar hakkında düşündüklerini çok önemser. Her ne kadar İslam'a geçmek teşvik ediliyor ve bu ödüllendiriliyorsa ${ }^{7}$ da, başka dinler ve inançlar hakkında Osmanlı toplumunda saygı ve değer verme ilkesini çıkarabiliriz. Müslümanlar,
İsa'nın bütün peygamberlerin en üstünü olduğuna ve asla günah işlemediğine, başka hiç kimsenin onunla eşit olmadığına da inanırlar. Yalnız İsa'nın çarmıha gerildiğine inanmazlar. Hatta onlara göre, Hıristiyanların bu inançları, İsa Tanrının en yakını ve asla günah işlemediği halde, çarmıha gerildiğine inanmaları, kötü ve yanlış bir inançtır. Eğer İsa tamamen suçsuz ve, günahsız, çarmıha gerilmiş olsaydı, o zaman Tanrının adil bir hâkim olmaması gerekirdi. (...) Fakat onlarca Muhammed, Allah'ın gerçek elçisidir. Onların kanaatına göre de İsa, Tanrının en yakın, en şerefli dört kişi arasındadır. O, mahşer gününde bütün insanları yönetecektir. (1995: 168 vd.)

Schiltberger'in bahsettiğine göre aynı şekilde Türkiye'nin o tarihlerde başkentliğini yapan ve iki yüz bin haneden oluşan Bursa'da Hıristiyan, Müslüman veya Yahudi olduğuna bakılmaksızın fakirlerin tedavi edildiği sekiz adet hastane bulunmaktadır (1995: 101). Müslümanların da, Hıristiyanların kutsal saydığı yerleri ziyaret ettiğini belirten Schiltberger, o dönem toplumunun hoşgörüsü açısından önemli ipucu vermektedir (a.g.y.).

\footnotetext{
${ }^{7}$ Müslümanlığa geçen erkek ve kadınlara düzenlenen tören ve ödüllendirme için bkz. J. Schiltberger 1995: $165 \mathrm{vd}$.
} 
Schiltberger, Müslüman Türk toplumunda Ramazan ve Kurban bayramlarının kutlanışı, anlamları ve adetleri hakkında bilgi verir (157-159). Özellikle Kurban bayramında kesilen kuzu ve sı ğırların, Allah rızası için ve İbrahim Peygamber'in şerefine fakirlere dağıtılmasını vurgular. Şarabın Müslümanlara neden yasaklandığını anlatma gereği duyan Schiltberger, alkolün insanları kavga ve çatışmaya sevk ettiği riskini ön plana çıkarmaktadır (162).

„Muhammed, herkesin besleyebileceği kadar karı almasına izin vermiştir.“ (161) diyen Schiltberger, kural olarak erkeklerin doğum yapan kadınlara on dört gün geçinceye kadar yanaşmadığını, Müslümanlara domuz etinin yasak olduğunu ve ancak kanı akıtılarak kesilen hayvan ve kuşların etinin yenilebileceğini belirtir.

\section{Hans Ulrich Krafft ${ }^{8}$}

H.U. Krafft'ın anılarını Almanya'da yayımlayan Klaus Schubring (Krafft 1970), yazdı̆̆ önsözde, O’nun hem kişiliği hem yaşadığı ve çalıştığı ortam üzerine, hem de anıları nasıl yazdığı ve bunların daha önce yapılmış baskıları üzerine ayrıntılı bilgiler aktarır. Turgut Akpınar da, bu Önsöz'ü kitabın başına koymuştur (Krafft 1996: 5-15). Schubring önce H.U. Krafft'ı tanıtır ve onun Türkiye serüvenini özetler. Ticareti öğrenmek üzere yurtdışı görevlere gönderilen Krafft, 1568'de Floransa'ya gider. Burada tanıştığı ve Mısır'dan gelen Alman tacirler genç Krafft'a, daha sonraki yaşamını belirleyecek olan ilk izlenimlerini kazandırırlar. Bu konuda daha sonra şöyle diyecektir: "Bu insanlardan, başarll ve şanslı geçen seyahat izlenimlerini, Türklerin gelenek ve adetlerini öyle sevinçli bir merakla dinliyordum ki, o zamanlar, iyi bir firsat düşerse bu şark ülkelerine gidip kalmayı arzu ediyordum." (1996: 10)

Bu ilginçtir, çünkü her ne kadar Osmanl1-Türk tehlikesinin gündemde olduğu o tarihlerde Almanya'da bu ezeli düşman hakkında anlatılan yeni olaylar ve gerçeklere karşı büyük bir bilgi merakı var idiyse de, Hans Ulrich Krafft'ın yaptığı gibi - gençliğin enerjisiyle, katışıksız ve çekincesiz bir ilgiyle - Türklerin yaşadığı bölgeye gitmek için yola çıkmak isteyenlerin sayısı çok değildir.

Hans Ulrich Krafft, nihayet 1573'de yine Augsburg'a geri döndüğünde bu firsat ortaya çıkar. Fransızların yanında Doğu Akdeniz ticaretine katılan önemli Alman firmalarından olan Manlichlerin emrine giren Krafft, efendilerinin mülkündeki gemilerden söz etmektedir.

Bunlar Fransız bayrağı çekerek firmanın Doğu'daki şubelerine; İstanbul'a, Kıbrıs'ta Magosa'ya, büyük ticaret merkezi Halep için, Suriye kıyılarındaki liman kenti Trablus Sam'a ve İskenderiye'ye hareket ederlermiş. Almanya'dan esas itibariyle demir küçük eşya ihraç ediliyor, buna karşılık hurma, üzüm, uyuşturucu, merhem, pamuk, halı ve değerli taşlar gibi Doğu'nun ünlü efsanevi ürünleri ithal ediliyormuş. Duruma göre Manlichlerin bir gemisi Lizbon'a ya da İngiltere'ye dümen kırıyormuş. Halep, Trablus Şam ve Magosa'daki şubeler için firma, 1573'ten itibaren ortak bir iş yöneticisi

\footnotetext{
${ }^{8}$ Aşağıdaki notların bir bölümü için bkz. Öztürk: 1997c, s. 10-11.
} 
öngörmüş. İşte bu görevi Hans Ulrich Krafft üstlenecek olup beraberine üç istasyonun sağlık gözetimi için ünlü Augsburglu Dr. Leonhardt Rauwolf verilmiş.

Hans Ulrich, 1574'de vardığı Trablus Şam'da doğu dünyasının zenginliklerini tam olarak tadamadan aynı yıl, 10 Ağustos'ta Augsburg'daki efendilerinin iflas ettiği haberini alır. Augsburg'da bu tarihlerde iflas etmek olağan bir olaymış, ancak bu Krafft'ın kaderinin değişmesine engel olmaz. Efendilerinin mali durumuna güvenerek, bir gemiyi doldurmak amacıyla bizzat borçlandığından, Kaufbeurenli bir Alman ve bir Fransızla birlikte 24 Ağustos 1574'de borç yüzünden Türk hapsine düşer. Yalnızca Dr. L. Rauwolf hapsedilmekten kurtulur, çünkü o sırada Mezopotamya gezisinde bulunmaktadır.

Kaufbeurenli iş arkadaşı, ağır hastalığından dolayı evinde gözetim altında kalabilecektir. Ancak çok geçmeden ölür. Fransız memur da hapse girişinden iki yıl sonra ölür. Krafft tek başına kurtulmak zorundadır. Bir hapishaneden öbürüne nasıl nakledildiği, yıllar süren hapis yaşamının nasıl geçtiği, mahpus olarak sonunda kurtuluşunu nasıl hazırladığı, azat edilmesinin nasıl gerçekleştiği konuları Krafft'ın notlarında ayrıntılı olarak anlatılmaktadır: Şehir hapishanesindeki sağlık koşulları korkunçtur. Bir keresinde eline çok miktarda ilaç geçince, mahpus arkadaşları arasında doktor olarak çalışmayı denemiş, Arapça okuyup yazma firsatını değerlendirmiş, fakat bunda ilerleme kat ettiğini görünce, Türk olmaya zorlanacağından korkarak bile bile kalın kafalıymış gibi davranmıştır. Süabyalı tacir, şehir hapishanesinde duyduğu "Binbir Gece Masalları" üslûbundaki hikâyeleri doğru-yanlış bakmadan, notlarına katmıştır (1996: 10-18).

Hans Ulrich Krafft, 24 Ağustos 1577 'de borç yüzünden düştüğü hapishaneden tahliye edilir ve birçok zorluktan sonra 1578 'de memleketine ulaşır.

Krafft'ın kişiliği ile ilgili bilgiler şöyle: sadık bir Protestan kimliği ile o, içine düştüğü sıkıntı ve tehlikelerde özellikle gösterdiği gibi, Tanrı'ya yönelişlerde bulunur. Yaşadığı dönem için ender bir tutumla, diğer dinlerden ve mezheplerden olan kişilere karş1 hoşgörüsünü ortaya koyar. Ölümünün ardından hep övgüyle, doğruluğu ve dürüstlüğüyle anılmıştır. Kişiliğini tamamlayan önemli bir özelliği de hiç bozulmayan mizah anlayışı ve isabetli esprileridir. Bunu okuyucular, Krafft'ın notlarından ${ }^{9}$ bizzat tadabilirler (bkz. 1996: 20).

\footnotetext{
9 Krafft'ın günümüze intikal eden yaşam anıları bugün Ulm şehir arşivinde, $H$ - Handschriften [Elyazmalart], Nachlässe [Yazarlardan kalan], Krafft, Hans Ulrich katalog bilgisiyle bulunabilir. Bundan bir kopya Ulm şehir kütüphanesinde (Handschrift 6 137), bir de aile üyelerinin mülkünde olmak üzere Essen-Bredeney'de bulunmaktadır. Hans Ulrich Krafft'ın anılarından seçme yapılarak ilk defa, kısmen yanıltıcı biçimde, rahip Schmid tarafından 1787'de, Aydınlanma akımını teşvik için yayımlanmıştır (Schwäbisches Magazin, Bd. II, s. 649 ve devamı). Bir bütün olarak ilk baskısını ise K.D. Hassler 1861'de gerçekleştirir (Reisen und Gefangenschaft Hans Ulrich Kraffts aus der Originalhandschrift, Bibliothek des Literarischen Vereins in Stuttgart, Bd. 61). Baz1 okuma ve bask1 hataları dışında bu baskı çok güvenilir bir durumdadır. 1862'de de A. Cohn'un hazırladığı bir yayım yapılır (Ein deutscher Kaufmann des sechszehnten Jahrhunderts - Hans Ulrich Kraffts Denkwürdigkeiten). Bu baskıda, bir bütün olarak bakılınca, 19. yüzyıl yazı diline yapılmış düzenli, tam bir çeviri söz konusudur; ekler de ihmal edilmemiştir.
} 


\title{
2.2. Krafft'a göre Osmanlı Toplumunda Sosyal Değerler
}

\subsubsection{Dinde Hoşgörü ve Saygının Ölçüsü}

Farklı dinden (Hıristiyan) biri olarak yabancı bir toplumda yadırganacak ilk husus, kişinin normal hayatında alıştığı şeyleri (davranış, yeme-içme, giyim-kuşam vb.) yapmaya kalktığında yaşayabileceği sürprizlerdir. Krafft'ın günlük hayatının, hatta dini ritüellerin bir parçası olan "şarap içme" özgürlüğünü Osmanlı toplumunda yaşayabilmesi onun notlarına yansımıştır.

\begin{abstract}
Burada Hıristiyanlar şarap içebilirler; onlara şarabı evlerinde bulundurmalarına müsade edilmiştir. Fransız ve Venediklilerin hiçbir işine karışılmaz, tamamen serbesttirler. Bununla beraber şarabı itina ile ve gizli olarak getirmelidir. Öyle ki şarap, muteber bir Türk veya zenci’nin evinin veya dükkânının önünden geçerken kokusunu duymasın. Bu konuda dava edilenler, cezasız kurtulamazlar. Tutuklanmamdan önce kendi evim vardı. Adamlarım günün birinde boş bir şarap fiçısını temizlediler, dikkatsizce iki litreden fazla olmayan kirli suyu sokağa döktüler. Bir saat bile geçmeden adli makamlara başvurularak, Müslümanlara karşı küstahlığımdan dolayı şarabı sokağa döktürdüğüm iddia edildi, bu suçlama bana 6 Duka altınına mal oldu. (1996: 51)
\end{abstract}

Osmanlı'nın baskın kültürün temsilcisi olarak, Müslümanları rahatsı etmeden farklı dinden olanlara şarap özgürlüğü sunması, ancak, yazılı ve/ya sözlü toplumsal uzlaşmaya aykırı davrananı cezalandırması anlaşııır niteliktedir.

\subsubsection{Dinde abartı/gösteriş/münafıklık}

Bize Krafft'ın din ve dil farkı dolayısıyla anlamakta zorlandığını düşündüren bazı notlarını, her şeye rağmen dikkate aldığımızda; bir yabancının gözünden Müslüman din adamlarının cahilliği, insanların bu kişilere körü körüne inanarak sorgulamaması ve abartılı dini telakkilerin ön plana çıkarıldığını görüyoruz.

Tevkifimden önce ve henüz iyi bir itibarım varken, evimin yakınında, yaklaşık kırk-elli adım ötede, Subaşının evi bulunuyordu. Onun yanında ise bir Müslüman din adamının evi bulunuyordu. Bu adam gerçi cahil bir eşeğin biriydi fakat kendi cemaati içinde bir Aziz telakki ediliyordu. Bu Hoca, Subaşının şerefine ve mürailiği ve riyakârlı̆̆ yüzünden bazen gece yarısı yahut gündoğumundan üç saat evvel, onun evine karşı vaazda bulunuyordu (?).

Evvela ürküntü veren bir bağırma ile başlıyor sonra da yüksek sesle, Tanrı'nın, merhametli olduğu, kötü dünyanın batmamasını sağladığını haykırıyordu.

$\mathrm{Bu}$ esnada dört ilâ altı kere "Tanrım.. Tanrım, bunlara nasıl müsade edip seyirci kalıyorsun” diye bağırıyordu. Sonunda da Tanrı'dan, fakir ve aciz Türklerin ve Arapların inançlarını kuvvetlendirip muhafaza etmesini diliyordu. (1996: 51-52) ${ }^{10}$

Yukarıda verdiğimiz örnek münferit bir olay olduğu halde (nitekim Krafft bundan bir kez söz ediyor), yine de göze batan bir sosyal problem olarak değerlendirilmelidir.

\footnotetext{
10 Anılarının burasında Krafft, Müslümanların dinî ibadetleriyle ilgili bir not düşmüş. Bir bölümü yakıştırma olduğu anlaşılan ve karşılaştırma biçiminde dile getirilen gözlemleri için bu sayfalara bak1labilir.
} 


\subsubsection{Oruç Geleneği}

Orucun Müslüman bir toplumdaki tartışılmaz yeri ve önemi dışında Krafft'ın notlarına yansıyan bir husus dikkat çekicidir. Orucun, bireysel (yeme-içmeden bir süre kaçınmak) yönünden ziyade sosyal dayanışmayı gerektiren bir ritüel ve pratik olduğunu, Krafft bir ecnebi olarak hapishanede bizzat tecrübe etmiştir.

Oruç tutacakları zaman, bunu Ramazan ayında, günlerin en kısa olduğu ayda yaparlar $(?){ }^{11}$

Bazı takva sahipleri, güneşin doğuşundan batışına kadar en ufak bir şey yeyip içmektense kafalarını kestirmeye razı olurlar. Bu işleri isteyerek yapan olursa aşağılanır, lanetlenir hatta dayak cezasına çarptırılır. Buna mukabil bütün gece, ertesi gün oruç tutabilmek üzere iyice yeyip içebilirler. Y1l boyunca, Ramazandaki gibi, nefis ve iyi yemekler yemezler. Hapislik süremin en iyi günleri Ramazanlardı çünkü biz mahpuslara Allah rızası ve mübarek günlerin şerefine o kadar çok ve iyi yemekler taşıyorlardı ki, ne gündüz ne gece, yiyip bitiremiyordum. (1996: $53 \mathrm{vd}$.)

\subsubsection{Evlilik Hukuku}

Eski Müslüman Türk toplumunda evlilik kurumunun işleyişi yabanc1 gözlemciler tarafından hep önemsenmiştir; İslam'ın Avrupalı tasavvurunu harem, odalık ve cariye gerçeğiyle süsleyen çok evliliğe cevaz vermesi ve bu uygulamanın gerçek hayata yansıyan yönleri, haliyle seyahatnamelerde karşılığını bulmuştur.

Müslümanlar, hatta zanaatkarlar (fakirler) bile iki, üç, dörde kadar kadınla evlenebilirler. Zenginler ve durumu refahlı olanlar daha çok kadın alabilirler. Paşalar, Beyler, Kadı ve Defterdar gibi yüksek idareciler, on-yirmi hatta, servetine göre, bakabileceği kadar kadın alabilir. Onlar bu işi Hıristiyanlıktaki çok veya az at sahibi olmak gibi telakki ederler. Biz Hıristiyanlarda tek bir eş'den fazlası mümkün değildir. (...) Nihayet basit adamların eşleri, kocaları onların hakkını vermezse ve onlara meyilleri kalmaz, ve başkasını severse, hakim önünde dava etme hususunda hak ve hürriyete sahiptirler. Kadın böyle bir adamdan ayrılmak istemiyorsa, ya şikayet etmeksizin buna katlanmaya veya daha büyük bir cezaya razı olmaya mecburdur.

$\mathrm{Bu}$ şekilde dava edilen adamlardan birçoğu bizim Hapishaneye düşmüştü. Bunlar hiddet, şiddet ve sabırsızlık içinde içeri girince, biz diğer mahpuslar, onları büyük bir tahta kaşık, (kepçe) içinde bir yudumluk su ile ve alaylı bir şekilde, acıyarak karşılardık. Böylece o kimse hiddetini soğutur ve sabırlı olursa kısa sürede durumu daha iyileşirdi. $\mathrm{Bu}$ arada arkadaşları onunla gayrı memnun karısının aralarını bulmaya gayret ederlerdi. Daha sonra o kişi, daha az bir alay ve zararla üç dört gün veya daha uzun süre sonra serbest bırakılırdı. Böyle bir ahvalde, özellikle biz Almanlar kadının dayaktan postunu çıkarırdık. (Krafft 1996: 54 vd.)

Kadınların çok eşli kocalarına karşı haklarını göstermesi bakımından Krafft'ın not ettiği husus çok önemlidir.

\footnotetext{
${ }^{11}$ Çev. T. Akpınar'ın notu: “Görülüyor ki Krafft birçok hususu yanlış bilmektedir.” (1996: 53).
} 


\subsubsection{Resmi Görevlilere Rüşvet/Bahşiş/Hediye Verme Âdeti (?)}

Hans Ulrich Krafft'ın gözlemleri elbette bunlarla sınırlı değil. O'nun en çok şikâyet ettiği konular arasında hapishane hayatı boyunca, içinde yaşadığı zorlukları bir ölçüde hafifletebilmek amaciyla, bahşiş veya her ne ad altında olursa olsun, resmi görevlilere vermek zorunda kaldığı rüşvet. Kad1, vali (1996: 98), güvenlik mensupları, hizmetkârlar, hepsi bir şekilde bahşiş talep ediyor ya da rüşvet (hoş görünmek için bir şey takdim etmek) (1996: 100) kabul ediyorlar.

Krafft, dayak, hücre vb. gibi cezalara maruz kalmaması için istenen hediyeleri almak üzere sürekli para aramak zorunda kalır (1996: 81 vd.) ve bir yaşlı Türkün kendisiyle ,,çünkü parası olmayanın, işinin yürümeyeceğini söyleyerek alay etti”ğini (1996: 82) ekler. Bu sebeple 6 Şubat 1575'te Sultanın alacaklarını tahsil etmek üzere Trablus'a gelen vekili memnun etmek için ipekli kumaş alması gerektiği söylenir ve sağdan soldan para tedarik etmeye koyulur (1996: 85), başaramaz ve kötü muameleye maruz kalır. Hapiste zincire vurulacakken, yine rüşvetle zincirden kurtulduğu (1996: 84) gibi, hediye kumaş karşılığı hücreden çıkarılır. Sadece Vekilin değil, onun hizmetkârlarının da gönlünü hoş tutmak zorunda kalır (1996: 86, 87); „Efendileri gider gitmez, önemli hizmetkârların tümü benim ve tercümanımın etrafina üşüşüp, bahşiş istemeye başladılar." (1996: 87) İstekleri arasında şarap ta vardır. Nitekim bolca içip sarhoş olurlar ve ertesi gün efendileri şarap kokusunu almasın diye, içtiklerini kusarlar. Rüşvet ve bahşiş vermek (1996: 92) suretiyle hapis hayatını kolaylaştıran Krafft, yine hapishaneden tahliye edilmek için para verdiği Kadı'nın kalbi yumuşasın diye en sevdiği beyaz tenli karısına gizlice ipekli iki elbise aldırarak (1996: 120) kurtulur. Kadın, kocasının hediyenin etkisiyle alacağı tahliye kararından dolayı Tanrının rahmetine mazhar olacağı kanaatindedir (!). Bu çelişkili durumu bir Ağa (Yüzbaşı)'nın tutumunda da görüyoruz. Kendisi ve oğlu için aldığı para hediyesinden (rüşvetten) sonra onun işini iyi yapacağına dair ,,şerefi ve dini üzerine yemin eder...” (1996: 113)

\subsubsection{Geleceği Görme İsteği/Falcılık}

Krafft'ın notlarında, Osmanlı Türk toplumunda (özellikle ay tutulması gibi Allah'ın takdiriyle olacağına inandıklarına vakıf olan) bilgiye (1996: 105), geleceği görme becerisi iddiasındaki falcıya (1996: 106) ve cenazeye (1996: 102) gösterilen saygıyı gözlemliyoruz. Osmanlı devletindeki müneccimlik kurumu, falcılığa olan merakın resmi bir yansıması olmalıdır.

\subsubsection{Kıskançlık}

Türk erkeklerinin kendi kadınlarını kıskandıkları, kadınlarını bu sebeple tesettür içinde tuttukları, umuma açık yerlerde (eşleri dahi olsa) kadınlarla konuşmaktan imtina ettikleri vurgulanır. Krafft'a göre bu ,kadına güven duymayan bir klskançlıktır” (1996: 108). 


\section{Bulgular ve Değerlendirme}

\subsection{Sakal ve Kibir iliş̧kisi}

Schiltberger'de sakal, Tanrının yarattığı gibi görünmek bağlamında (traş olunarak dünyada hoşa gitmek için süslenildiği anlamında) kibir ve mağruriyet görüntüsü vermemek bakımından önemseniyor. Aynı husus Hıristiyanlarda da eleştirilmekte, sakalın karılarının hoşuna gitmek için kesilmesi züppece bir davranış olarak görülüyor. $\mathrm{Bu}$ tespitten yola çıkarak, kibir, mağrurluk ve züppelik tersten bakılınca alçak gönüllülüğ̈̈n, tevazuun ve toplumun hoş gördüğü davranışların aksini ifade eder. Nitekim kibrin insanı ahlâken bozacağına ve alçak gönüllülügün ise Tanrı katında mükâfatlandırılacağına dair notlar bunu desteklemektedir. Zenginin fakire karşı alçak gönüllü olup, yardımlaşma ilkesine göre hareket etmesi gerektiği (Kurban Bayramı kapsamında da) hatırlatılmaktadır.

\section{2. İnanca saygı}

İkinci husus din bağlamında, başka peygambere ve kitaba inananlar hakkında Osmanlı toplumunda görece bir saygı olduğunu bulguluyoruz. Değişik ifadeyle, yan yana yaşayan ve farklı dinlerden insanların biri birlerini (dindeki) benzerlikler üzerinden anlayabildiğini görüyoruz. Bunu din değiştirmek isteyen Hıristiyanlar için düzenlenen tören esnasında, Schiltberger'e göre Kelime-i şehadet dışında seslice söylenen sözlerde de anlıyoruz: "Tanrı birdir. Mesih onun kuludur. Meryem karabaşıdır (kadın kuludur), Muhammed resulüdür.” (Krafft 1996: 166)

Schiltberger'in notları arasında gösterişli din değiştirme töreni ve bunun maddi olarak da ödüllendirilmesiyle teşvik edildiğini gördük; bu hususun Krafft tarafindan da, Müslüman olmaya "zorlanacağını" düşünerek Arapça bildiğini saklamak istemesinde ima edildiği görülüyor.

Tevazuu Cuma günü camiye giden Müslümanlarda gözleyen Krafft, Osmanlı toplumunun hoşgörüsünün ancak kendisini rahatsız etmemek şartına bağlı olduğunu belirtiyor. Örn. Müslümanlara göstermemek ve rahatsız etmemek şartıyla şarap içebilirler. Eğer bu şartı yerine getirmezler ise cezalandırılırlar. Bu ise dinde sınırsız bir hoşgörü olmadığı anlamına gelmektedir.

Krafft, Ramazan aylarını kast ederek, ,tutsaklığım süresince, en güzel zamanı bu aylarda geçirdim, öyle ki, Tanrı ve mübarek ay hürmetine biz tutsaklara o kadar yemek getiriyorlardı ki gece-gündüz bunların yiyip bitiremiyordum." demektedir. Bu gözlemde, oruçla birlikte fakir ve mağdurlara bol bol ikram ve yardım yapıldığı anlaş1lıyor. Buna ecnebi mahkûmların da dâhil olduğu görülüyor. 


\subsection{Kadının konumu}

Evlilik kurumu açısından, kadınların, kocalarını, şayet haklarını vermiyor, ondan artık hoşlanmiyor ve başka birini seviyor iseler, hâkime şikâyet edebilme âdeti ve özgürlüğüne sahip olduğu ve böyle bir adamın cezalandırıldığg belirtilmektedir. $\mathrm{Bu}$ ise sosyal değer olarak kadın haklarında çok ilginç bir durumu ortaya çıkarmaktadır. $O$ tarihlerde böyle bir uygulamanın Avrupa'da olmadığ 1 dikkate alınırsa, durumun ilginçliği daha da belirginleşmektedir. Uyuşmazlık halinde erkeğin hapse düşmesi ve evliliğin kurtarılması adına arabulucuların devreye girmesi de önemlidir.

\subsection{Adaletin işleyişi ve Bahşiş ve/ya Rüşvet sorunsalı}

Krafft'ın hapse düştüğü dönemde en büyük probleminin görevlilere vermek zorunda bırakıldığı bahşiş/rüşvet olduğunu gördük. Oysa Krafft, bir keresinde İstanbul'daki Sultanın (Kanuni Sultan Süleyman), rüşvetle tebaaya haksızlık eden bir Kıbrıs Paşasına ölüm cezası verdiğine tanık olmuştur: „Paşa, [ölüm] fermanı[nı] tebaaya, kullara yakışır bir şekilde eğilerek aldı, bağını çözdü ve içindekileri okudu. Fermanda evvelce ikaz edilmesine rağmen adalete ve devlet düzenine şiddetle ihtiyacı olan tebaasına karşı haksız şekilde davrandı̆̆ından, mektubu getirenle kendi kellesini Sultana göndermesi gerektiği yazılıydı." (1996: 43)

Rüşvet alarak haksızlık yapan Paşa, „Bismillahirrahmanirrahim” diyerek karşıladığı ölüm fermanı üzerine önce namaz kılar, eşleriyle vedalaşır ve zehirli şişeden içerek ölmeyi seçer. Fermanı getiren çavuş, Paşanın yerine Defterdarın atandığını söyleyerek onu makamına kadar getirip , herkesin verdiği emirlerde dikkatli olmasını ve orada yatan cesedi örnek olarak hatırlamasını, zira Allah'ın ve Türk Sultanı'nın haksılıkları cezasız bırakmayacağını bilmesi gerektiğini” (1996: 44) ihtar eder.

Kadı'nın Krafft hakkında (üç yıllık hapis hayatı sonunda) geciken tahliye kararını verirken dayandığı gerekçeleri dikkate aldığımızda, adaletin tecellisi için (rüşvet, hediye, bahşiş gibi) başka bir araca gerek duymaksızın makul bir mantık muhasebesinin yapılabildiği görülüyor: 1) Vatandaş, yargıya tabidir. 2) İddia sahipleri mahkemeyi yanıltmamalıdır. 3) Asıl borcu aşan faiz olamaz ve bu hapis için hesaba katılamaz. 4) Borçlunun hapiste ölmesi davaya çözüm değildir. 5) Borçlunun tutuklanması, borcun ödenmesini sağlamaz. 6) Başkasının emrinde çalışan kişi, emrinde çalıştığı kişinin borcundan sorumlu tutulamaz (bkz. 1996: 127).

Tüm bunlara rağmen tahliye edilen Krafft, gönüllü olarak etrafa saçtığı paralar sayılmazsa, yine hem Kadı'ya hem de Ağa (Yüzbaşı) tarafından karısına ve kendisine hediye almak zorunda birakılır (bkz. 1996: 130). 


\section{Sonuç}

J. Schiltberger ile H.U. Krafft'ın yüz elli yıl arayla yazılan notları elbette normal şartlarda yapılmış bir seyahatin ürünü değildir. İlki tutsak olarak kalmış ve daha çok birinin emrindeki köle olarak seferlere katılmış, sokaktaki hayata uzak kalmıştır. Diğeri ise başkasının borcu yüzünden hapse atılmış ve oradaki yaşantılarını yazıya geçirmiştir. Borç davası sebebiyle muhatap olduğu kişiler ve maruz kaldığı suç isnadı, entrika, kıskançlık ve rüşvet talepleri gibi adli ve adi vakalar daha çok gündemine girmiştir.

Schiltberger'in 15. yüzyıla tanıklık eden notlarında daha çok din farkı ve farklı din ve etniler arası ilişkiler yer tutuyor. Bunda elbette onun seferler sebebiyle devamlı farklı insan ve kültür çevreleriyle karşılaşmış olması rol oynamıştır.

Müslümanlarda dini gerekçeyle sakal bırakmayı açıklarken, arkasında yatan "Yaratana ve onun yarattığına saygı" düşüncesini; Tanrı'nın yarattığını, insanlara hoş görünmek için değiştirmeye kalkmanın kibir, mağrurluk ve züppelik olarak değerlendirilmesini önemli bir sosyal değer saymak gerekir. Çünkü burada inanç ve günlük hayat arasındaki tutarlık ilkesi vardır.

J. Schiltberger'in Müslümanlar örneğinde açıkladığı gibi, dinlerin benzerliklerini ön plana çıkarmanın farklı dinden insanlarla biraradalığı kolaylaştıracağı ilkesi önemli görünüyor. $\mathrm{Bu}$ ise günümüz perspektifinden Avrupa'da yaşayan Müslümanlar için olduğu kadar kendi ülkemizde de var olan farklılıkları hoş görebilmenin en makul yollarından birisidir.

H. U. Krafft ise kendisine suç isnat edilen bir mahpus olarak, J. Schiltberger'e göre daha derinden yaşamıştır yabancılık ve ötekilik olgusunu. Sosyal hayatın daha çok hukuki boyutuyla muhatap olduğu için, cezalandırılan ya da cezalandırılmayan davranışları gözleme imkânı bulmuştur.

Bir Hıristiyan olarak şarapla ilgili tecrübesi, bize sosyal bir değer olarak Müslümanlarda dinde hoşgörü ve saygının ölçüsünün sınırsız olmadığını anlatma imkânı verirken, gösteriş için gece yarısı veya sabaha karşı gürültülü vaaz veren hocanın kimliğinde mürai (dalkavuk, riyâkâr, münâfık) kişilikleri eleştirmektedir. Bu riyakârlık ve münafiklığı, ayrıca maaş karşılığı yapmak zorunda oldukları işleri rüşvet, bahşiş, hediye vb. kabul ederek güya kolaylaştırıcı olma iddiasındaki kişilerde de görüyoruz. Bu hususları sosyal değer olarak değil, eksiklik olarak nitelemek daha doğru olacaktır.

H.U. Krafft'ın dini bir pratik olarak önemle bahsettiği Ramazan Orucu hakkında söyledikleri ve Müslüman kadınların evlilik içinde kocalarına karşı haklarına ilişkin hayretle not ettikleri, kanaatimce sosyal açıdan yüksek değerdedir. Oruç, yardımlaşma/dayanışma demektir ve bu yardımlaşma Osmanlı toplumunda hapishanedeki ecnebi mahpusları bile kapsamaktadır. Kadın, evlilik hukukunda eğer kocası tarafından ihmal edilir ve haksızlığa uğrarsa şikâyet edip onu hapse attırabilir. $\mathrm{Bu}$, o zamanın Avrupa'sına kıyasla çok olumlu bir durumu yansıtmaktadır. ${ }^{12}$

${ }^{12}$ Elbette bu seyyahın bakış açısından böyledir. Gerçek durumu ortaya koyabilecek karşı okumalar bu 
Evlilikte erkek kıskançlığı (bakış açısına göre olumlu ya da olumsuz değerlendirilebilir) Krafft tarafından özellikle kadınların sokaktaki hareket özgürlügünü kısıtlayan bir faktör olarak yorumlanmış. Kadın ve erkeğin (karı-koca olsalar bile) sokakta, umuma açık yerlerde konuşmalarının hoş karşılanmaması sosyal açıdan ilginç bir durumu sergiliyor. İki kişinin herkesin gözü önünde konuşması toplumu neden rahatsız etmektedir? Ne konuştukları, mahremleri, diğer insanları neden ilgilendirmekte, bireyin merak duygusuna Müslüman toplumda neden bu kadar izin verilmekte ve teşvik edilmektedir? Müslümanın kusurunu örtmeyi emreden bir dinin mensupları, masum durumlardan neden potansiyel kusur yaratma eğilimindedir, sorgulanmalı ve bunun bir sosyal değer mi yoksa değersizlik mi olduğu tartışılmalıdır.

Krafft'ın Osmanlı Devleti'nin en muhteşem yüzyılında Türklerin ve Arapların arasında yaşadığını tekrar göz önüne alırsak, notlarında sıklıkla şikâyet ettiği rüşvet, bahşiş, hediye vb. ile iş yaptırma sorunu kanaatimizce en önemli husustur ve bu makalenin (devletin en muhteşem dönemi için) en şaşırtıcı sonucudur. Resmi görevlilere rüşvet, bahşiş, hediye vermek nerdeyse adet (?) haline gelmiş görünüyor. "Parası olmayanın, işinin yürümeyeceği” (1996: 82) iddiası çok vahimdir. Bunu da sosyal açıdan anti değer olarak görmek zorundayız. Bir elektronik Íslam Ansiklopedisi'nde

\footnotetext{
İş, söz ve davranışlarda gösterişe yer verme; bir iyiliği veya salih bir ameli Allah'ın rızasını kazanmak niyetiyle değil, insanların beğenisi için yapma. Bu davranışta bulunan kimseye riyakâr veya müraî denir.

Riya, insanlar arasında manevî nüfûz, şan ve şöhret, maddî çıkar sağlamak için yapılır. Dünyaya âit bu tür maddî ve manevî çıkarları elde etmek için, dinin insanlar tarafından kutsal değerlere karşı beslenen bağl1lık ve hürmet duygularının âlet edilmesi, riyanın en kötü şeklidir. (Şamil; 2016; bkz. ayrıca Bardakoğlu 1988: 87)
}

denilmektedir. Dolayısıyla yabancı perspektifinden bakılınca, bir toplumun dini değerler ve Allah rızası iddiasını geçersiz kılan kibir/gösteriş ile maddi çıkar sağlama eğilimi arasındaki bariz ahlaki çelişkisinin sorgulanması gerekmektedir.

Takvim bilgilerine göre ay tutulması olacağını bilebilen kişiyi cahillikten falcı olarak görme, onun geleceği bilebildiğini tasavvur ederek medet ummak da kanaatimizce Müslüman toplumun başka bir çelişkisidir. Bir yandan dini açıdan her şeyin Allah'tan geldiğine, kadere karşı gelinemeyeceğine inanan insanlar, "geleceği görme isteği”" ile "falcılara" büyük önem vermektedirler. Burada hem bilim-cehalet hem de iman-hurafe karşıtlığını görmemiz mümkündür.

\section{Kaynakça}

Akbulut, Nazire (2019): „Orient/ Anatolien in den deutschsprachigen Autobiographien oder Memoiren“. Ex Oriente Lux: West-östlicher Kulturtransfer. Hrsg. von Cemile Aky1ldız Ercan, Yasemin Balc1, Ali Osman Öztürk. Berlin: Logos Verlag, s. 129-144. (= Germanistik in der Türkei, Bd. 1)

Bardakoğlu, Ali (1988): „Riya Maddesi“. Kur’ân-ı Kerîm Ansiklopedisi (İlimler, Kavramlar, İsimler,

makalenin konusu değildir. 
Hükümler, Mekanlar), Cilt: 2., haz. Ali Bardakoğlu vd. İstanbul: Tercüman Aile ve Kültür Kitaplı̆̆ Yayınlar1, s. 87.

Béhar, Pierre (1994): “Türkenbilder, Italienbilder: Antithesen des Deutschen". Zeitschrift für Literaturwissenschaft und Linguistik 94 (1994), s. 92-107.

Buch, Wilfried (1982): “16. Yüzyılda İki Genç Alman'ın Türklerle İlgili İzlenimleri”. Belleten, Sayı: 184, Ekim 1982, Ankara: Türk Tarih Kurumu, s. 745-786.

Busbeck, Ogier Ghiselin von (1926): Vier Briefe aus der Türkei. Aus dem Lateinischen übertragen, eingeleitet und mit Anmerkungen versehen von Wolfram von den Steinen. Mit 20 Wiedergaben zeitgenössischer Holzschnitte. Erlangen: Philosophische Akademie.

Busbecq, Ogier Ghislain de (2011): Türk Mektupları. Kanuni Döneminde Avrupalı Bir Elçinin Gözlemleri (1555 -1560). Çev. Derin Türkömer. İstanbul: Türkiye İş Bankası Kültür Yayınları, 2011.

Çetin, Firdevs (2011): "XVI. Asır Alman Seyyahlarında Osmanlı (Türk) Toplumu ve İnsanına Dair Bilgisizlik ve Tarihi Önyargılar”. Kırıkkale Üniversitesi Sosyal Bilimler Dergisi, Cilt 1, Say1 1, s. 39-58.

Cohn, Adolf (1862): Ein deutscher Kaufmann des sechszehnten Jahrhunderts - Hans Ulrich Kraffts Denkwürdigkeiten. Vandenhoeck und Ruprecht's Verlag.

Dernschwam, Hans (1923): Tagebuch einer Reise nach Konstantinopel und Kleinasien (1553/1555), herausgegeben und erläutert von Franz Babinger, München und Leipzig.

Dernschwam, Hans (1992): Istanbul ve Anadolu'ya Seyahat Günlüğü, çev. Yaşar Önen, Ankara: Kültür Bakanlığı.

Güvenç, Bozkurt (1994): Türk Kimliği. Kültür Tarihi’nin Kaynaklarl. Ankara: Kültür Bakanlığı Yay. (= Genel Yayın: 1549, İnsanlık Tarihi Dizisi 2)

Hassler, Konrad Dieterich (1861): Reisen und Gefangenschaft Hans Ulrich Kraffts aus der Originalhandschrift, Bd. 61. Stuttgart, Literarischer Verein.

Krafft, H[ans] U[Irich] (1970): Ein schwäbischer Kaufmann in türkischer Gefangenschaft. "Reisen und Gefangenschaft Hans Ulrich Kraffts”. Bearb. von Klaus Schubring. Schwäbische Lebensläufe, Bd. 4. Hrsg. von Helmut Christmann. Heidenheim an der Brenz.

Krafft, Hans Ulrich (1996): Türklerin Elinde Bir Alman Tacir. Çev. Turgut Akpınar, İstanbul: İletişim Yayınları (= Genel Yayın no: 377, Tarih ve Politika dizisi: 14)

Önen, Yaşar (1977): „Hans Dernschwam’ın Gözü ile Kanuni Devrinde Türkiye“. Dünya Edebiyatından Seçmeler, Cilt: 1, Sayı: 4, Ekim, S. 1-16.

Öztürk, Ali Osman (1997a): “Johannes Schiltberger'in 'Türkler ve Tatarlar Arasında (1394-1427) Adlı Eserinde Adetler ve İnanmalar”. Türk Dünyası Tarih Dergisi, Say1: 124, Nisan 1997, s. 54-58

Öztürk, A. O. (1997b) “Johannes Schiltberger'in 'Türkler ve Tatarlar Arasında (1394-1427) Adlı Eserinde Adetler ve İnanmalar”. Türk Dünyası Tarih Dergisi, Sayı: 125, Mayıs 1997, s. 55-60.

Öztürk, A. O. (1997c): “Bir Alman Tacirin Anıları”. Cumhuriyet Kitap, Sayı: 373, 10.04. 1997, s. 10-11.

Said, Edward (1991): Oryantalizm: Sömürgeciliğin Keşif Kolu. İstanbul: Pınar Yayınları.

Şâmil, İ. A. (2016): Riya Maddesi. Islam Ansiklopedisi (http://samil.ihya.org/ansiklopedi/riya.html) $(29.09 .2016)$

Schiltberger, Johannes (1995): Türkler ve Tatarlar Arasında (1394-1427). Çev. Turgut Akpınar, İstanbul: İletişim Yayınları (= Genel Yayın no: 299, Tarih-Politika dizisi: 9)

Schlemmer, Ulrich (1996): „Türkler ve Tatarlar Arasında“ Üzerine“ (Çev. A. O. Öztürk). Tarih ve 
Toplum, Cilt: 25, Sayı: 146, Şubat 1996, s. 57-63.

Schmid (Vorname unbekannt) (1787): Hans Ulrich Krafft. In: Kerner, Johannes(Hrsg.): Schwäbisches Magazin zur Beförderung der Aufklärung, Bd. II, Ulm, s. 649-757.

Schweigger, Salomon (1964): Eine newe Reyssbeschreibung auss Teutschland nach Constantinopel und Jerusalem. Graz: Akademische Druck=und Verlagsanstalt.

Schweigger, Salomon (2004): Sultanlar Kentine Yolculuk, Çev. S. Türkis Noyan, Istanbul: Kitap Yayınevi.

Tebly, Karl (1988): Dersaadet'te Avusturya Sefirleri. Çev. Selçuk Ünlü. Ankara: Kültür ve Turizm Bakanlı̆̆ı (= No: 887, Tercüme Eserler Dizisi: 64). 